\title{
Immobilized Glucose Oxidase and D-Amino Acid Oxidase: A Convenient Method for the Purification of Flavin Adenine Dinucleotide and Its Analogs ${ }^{1}$
}

\author{
Vincent Massey and Loren D. Mendelsohn \\ Department of Biological Chemistry, The University of Michigan, \\ Ann Arbor, Michigan 48109
}

Received October 25, 1978

\begin{abstract}
The preparation of flavin adenine dinucleotide-affinity columns employing glucose oxidase and D-amino acid oxidase covalently linked to Sepharose-4B is described. Both immobilized enzymes have very good long-term stabilities, retaining at least half of their original flavin adenine dinucleotide-binding capacity over 11 months. In both cases pure flavin adenine dinucleotide is obtained readily in good yields.
\end{abstract}

One of the most promising recent developments in the flavoenzyme field involves replacement of the native coenzyme by artificial flavins of different spectroscopic and redox properties. From the work already published, this approach promises to yield much definitive information concerning the flavin binding domains of the various apoproteins (1-4), about the charge transfer nature of long wavelength absorbing species $(5,6)$, about covalent intermediates of flavin and substrate (7), and in general much information of use in detailed mechanistic studies (8). This development has been made technically possible largely because of the very wide specificity of a flavokinaseFAD $^{2}$ synthetase complex obtained from the microorganism Brevibactericum ammoniagenes. This enzyme system, in the presence of ATP and appropriate cofactors, will convert riboflavin and practically every artificial flavin so far tested which has a ribityl side chain to a mixture of the corresponding FMN-level and FAD-level forms

1 This paper is dedicated to the memory of $\mathrm{Dr}$. Alvin Nason.

${ }^{2}$ Abbreviations used: FAD, flavin adenine dinucleolide; FMN, flavin mononucleotide.
(3). These can generally be separated from each other and from starting material by ion-exchange chromatography $(3,9)$ or by selective adsorption to Sephadex or BioGel in column chromatography (3).

An alternative procedure, which has been very successful for the purification of flavins at the FMN level, is that of affinity chromatography. Most flavoproteins are quite specific for binding their flavin coenzyme either at the FMN or at the FAD level. Mayhew and Strating (10) made use of the high specificity for FMN of the flavodoxin from Peptostreptococcus elsdenii to develop an elegant method of purifying flavins with an $N(10)$-ribityl 5'-phosphate side chain. This they did by covalently attaching flavodoxin to CNBr-activated Sepharose 4B. The apoprotein could be prepared by stripping the native flavin with trichloroacetic acid; the FMN-binding properties of the apoprotein were substantially recovered on reneutralization of the column. This technique was employed by the authors for the preparation of ultrapure FMN and a number of FMN analogs with modified flavin ring systems (10). In the present paper we describe similar affinity chromatography procedures for the purification of flavins at the 
FAD level, employing the FAD-specific enzymes, D-amino acid oxidase and glucose oxidase.

\section{MATERIALS AND METHODS}

D-Amino acid oxidase was isolated from pig kidneys by the method of Brumby and Massey (11). Glucose oxidase was purified from Aspergillus niger as described by Swoboda and Massey (12). Sepharose 4B, preactivated by cyanogen bromide, was purchased from Pharmacia. All chemicals employed were reagent grade quality; glassdistilled water was used for all solutions.

Glucose oxidase affinity matrix. The CNBr-activated Sepharose 4B (4 g) was treated according to the manufacturers' instructions; it was suspended in $800 \mathrm{ml}$ of $10^{-3} \mathrm{M} \mathrm{HCl}$ for $15 \mathrm{~min}$, then filtered on a sintered glass funnel, and washed six times with approximately $50-\mathrm{ml}$ volumes of $10^{-3}$ $\mathrm{M} \mathrm{HCl}$ and then three times with $30-\mathrm{ml}$ volumes of coupling buffer $(0.1 \mathrm{M}$ pyrophosphate/ $\mathrm{HCl}$ plus $0.5 \mathrm{M} \mathrm{NaCl}, \mathrm{pH} 7.7)$. The washed CNBr-Sepharose was then suspended in a total volume of $17 \mathrm{ml}$ with coupling buffer containing $2 \mu \mathrm{mol}$ of glucose oxidase (expressed as FAD content). The mixture was stirred gently at room temperature for a period of $1.5 \mathrm{~h}$, when visually it appeared that most of the yellow color of the enzyme was bound to the solid matrix. The suspension was then packed into a column, washed with $40 \mathrm{ml}$ of coupling buffer to remove free enzyme, and then equilibrated with 1 м 2-amino ethanol in coupling buffer, with $\mathrm{pH}$ readjusted to $\mathrm{pH}$ 7.7. The equilibration was continued for $1 \mathrm{~h}$ to ensure complete blocking of reactive groups of the matrix by amino ethanol, before transfer to the cold room and equilibration with $0.1 \mathrm{M}$ phosphate, $\mathrm{pH}$ 6.3. The FAD prosthetic group of the covalently bound enzyme was eluted with a saturated $\left(\mathrm{NH}_{4}\right)_{2} \mathrm{SO}_{4}$ solution adjusted to $\mathrm{pH} 1.5$ at $0^{\circ} \mathrm{C}$ by addition of $\mathrm{H}_{2} \mathrm{SO}_{4}$. As the eluting buffer moved down the column the opaque matrix became translucent behind the front of highly fluorescent FAD released from the nonfluorescent holoenzyme. Elution was continued until no further fluorescence appeared in the eluate. The column was then washed with $0.1 \mathrm{M}$ phosphate, pH 6.3, the matrix again becoming opaque as the acid-ammonium sulfate solution was displaced. The column was then equilibrated with $2 \times 10^{-4} \mathrm{M}$ Sigma FAD dissolved in the washing buffer and closed off overnight before going through another cycle of elution and loading as described above. The flavin eluted quantitatively in a volume of approximately $50 \mathrm{ml}$. It was concentrated by extraction into approximately $5 \mathrm{~g}$ of phenol, from which it can be reextracted promptly and quantitatively by addition of $10 \mathrm{ml}$ of ether to the phenol phase and extraction into 1 to $2 \mathrm{ml}$ of $\mathrm{H}_{2} \mathrm{O}$. The aqueous phase was then washed several times with 5 to $10-\mathrm{ml}$ volumes of ether to remove phenol, and finally the ether was removed by evaporation.

For each subsequent loading and elution of the column, excess FAD and nonbound impurities were removed by washing with $0.1 \mathrm{M}$ phosphate, $\mathrm{pH} 6.3$, until the eluate was practically colorless. Then the acid $\left(\mathrm{NH}_{4}\right)_{2} \mathrm{SO}_{4}$ elution and regeneration procedure described above was followed.

D-Amino acid oxidase affinity matrix. The procedure followed for coupling of the enzyme was practically identical to that described for glucose oxidase, except that the coupling buffer was $0.02 \mathrm{M}$ pyrophosphate plus $0.5 \mathrm{M} \mathrm{NaCl}, \mathrm{pH} 8.0$, and contained in addition, $10^{-4} \mathrm{M}$ sodium benzoate (benzoate is a competitive inhibitor of the enzyme, and by binding strongly to the holoenzyme, but not to the apoenzyme, cnhances flavin binding). An amount of enzyme containing $1.75 \mu \mathrm{mol}$ of FAD was employed, and reacted for $1.5 \mathrm{~h}$ at room temperature before packing into a column and reacting with 2-amino ethanol. The column was then transferred to the cold room and equilibrated with $0.02 \mathrm{M}$ pyrophosphate, $\mathrm{pH} 8.5$, containing $10^{-4} \mathrm{M}$ benzoate. Stripping of the enzyme-bound flavin was accomplished with $2 \mathrm{M} \mathrm{KBr}$ dissolved in $0.02 \mathrm{M}$ pyrophosphate, $\mathrm{pH}$ 8.5. After the column was free of flavin 
(approximately $50 \mathrm{ml}$ of eluate) the apoprotein was equilibrated with $0.02 \mathrm{M}$ pyrophosphate, $\mathrm{pH} 8.5,+10^{-4} \mathrm{M}$ benzoate, and finally with the same buffer containing $2 \times 10^{-4} \mathrm{M}$ Sigma FAD. An equilibration period of at least $2 \mathrm{~h}$ was given to allow completion of holoenzyme formation before washing with $0.02 \mathrm{M}$ pyrophosphate, $\mathrm{pH} 8.5,+10^{-4} \mathrm{M}$ benzoate to remove unbound FAD and nonFAD impurities. The enzyme-bound FAD was then stripped with $\mathrm{KBr}$ as described above, and the whole cycle of washing and reloading was repeated. The FAD eluted from the column was recovered in a concentrated form by saturating the eluate with $\left(\mathrm{NH}_{4}\right)_{2} \mathrm{SO}_{4}$, extracting with phenol, and reextracting into water just as described for the glucose oxidase column.

\section{RESULTS}

Yield and stability of the affinity columns. The procedure described resulted in a $50 \%$ coupling of glucose oxidase to the CNBr-activated Sepharose $(0.98 \mu \mathrm{mol}$ of FAD recovered in the first elution). On reloading, the capacity of the column was found to drop to half of this value $(0.53$ $\mu \mathrm{mol})$ but remained unchanged for several subsequent reloadings over a period of 1 month. The capacity of the column for binding FAD dropped on being left incompletely loaded during a 2-week period; the capacity was then found to be $0.36 \mu \mathrm{mol}$ of FAD. However, the long-term stability when saturated with FAD is quite striking; 10 months later the capacity was still $0.34 \mu \mathrm{mol}$ of FAD. An attempt was then made to determine if the enzyme would tolerate stripping with $5 \%$ trichloroacetic acid, as done with the FMN-binding flavodoxin column. After such treatment, however, the FAD-binding capacity dropped from 0.34 to $0.19 \mu \mathrm{mol}$, indicating that this is not a suitable method of elution.

With the D-amino acid oxidase column the yield of enzyme coupled to the activated Sepharose was somewhat higher $(1.1 \mu \mathrm{mol}$ of FAD capacity from $1.75 \mu \mathrm{mol}$ of enzyme used in the coupling procedure). For the first five cycles of loading and stripping carried out over a 3-week period the capacity remained unaltered. After 5 months the capacity was found to be $0.63 \mu \mathrm{mol}$; after 11 months it was still $0.56 \mu \mathrm{mol}$.

Specificity. As was to be expected from the solution studies long reported in the literature, both columns were found to be specific for binding of flavins at the FAD level. Although the Sigma FAD used to equilibrate the columns was only about $85 \%$ pure (12), the flavin stripped from both columns and recovered by phenol extraction was quite pure as judged by thin-layer chromatography and fluorimetric analysis. Thus no FMN or riboflavin could be detected by thin-layer chromatography in a butanol-acetic acid-water (4:3:3) system or in $5 \% \mathrm{Na}_{2} \mathrm{HPO}_{4} \cdot 12 \mathrm{H}_{2} \mathrm{O}(13)$. The fluorescence of the isolated FAD in $0.1 \mathrm{M}$ phosphate, $\mathrm{pH} 7,20^{\circ} \mathrm{C}$ increases 11.5 -fold on conversion to FMN by the addition of a few grains of Naja naja venom, a potent source of phosphodiesterase. This fluorescence ratio is exactly the same as that reported previously for conversion of pure FAD to FMN (12). While the columns have not yet been examined systematically for binding of artificial flavins at the FAD level, solution studies with several such flavins indicate that these two enzymes are capable of binding tightly a wide variety of FAD analogs. Thus, the apoprotein of glucose oxidase has been shown to bind tightly with 5-deaza FAD (6), 1-deaza FAD (14), 8-chloro FAD (15), and 8-mercapto FAD (15). Similarly, the apoprotein of Damino acid oxidase has been shown to bind 5-deaza FAD (6,16), 1-deaza FAD (14), 8chloro FAD (15), 7,8-dichloro FAD (17), 8hydroxy FAD $(1,2)$, and 8-mercapto FAD (15). Both apoenzymes appear to bind the artificial flavins as tightly as or in some cases even more tightly than the native coenzyme, FAD. While this may not be true for all synthetic flavins, the availability of two different FAD-affinity columns would increase the likelihood of this method being of general utility in the purification of synthetic 
FAD analogs or of derivatives of FAD produced by chemical modification while bound to an enzyme.

\section{ACKNOWLEDGMENT}

This work was supported by NIH Grant GM 11106.

Note added in press. After this paper was submitted we found a paper by Yagi and coworkers (ref. 18) describing the properties of D-amino acid oxidase immobilized on a variety of supporting media.

\section{REFERENCES}

1. Ghisla, S., and Mayhew, S. G. (1976) Eur. J. Biochem. 63, 373-390.

2. Ghisla, S., Massey, V., and Mayhew, S. G. (1976) in Flavins and Flavoproteins (Singer, T. P., ed.), pp. 334-340, Elsevier, Amsterdam.

3. Walsh, C., Fisher, J., Spencer, R., Graham, D. W., Ashton, W. T., Brown, J. E. Brown, R. D., and Rogers, E. F. (1978) Biochemistry 17, 19421951 .

4. Moore, E. G., Cardemil, E., and Massey, V. (1978) J. Biol. Chem. 253, 6413-6422.

5. Abramovitz, A. S., and Massey, V. (1976) J. Biol. Chem. 251, 5327-5336.
6. Fisher, J., Spencer, R., and Walsh, C. (1976) Biochemistry 15, $1054-1064$.

7. Massey, V., Ghisla, S., and Choong, Y. S.. manuscript in preparation.

8. Walsh, C. (1978) Annu. Rev. Biochem. 47, 881 931.

9. Massey. V., and Swoboda, B. E. P. (1963) Biochem. 7. 338, 474-484

10. Mayhew, S. G., and Strating, M. J. J. (1975) Eur. J. Biochem. 59, 539-544.

11. Brumby, P. E., and Massey, V. (1968) in Biochemical Preparations (Lands, W. E. M., ed.), Vol. 12, pp. 29-41, John Wiley and Sons, New York

12. Swoboda, B. E. P.. and Massey, V. (1965) J. Biol. Chem. 240, 2209-2215.

13. Matsui. K. (1971) in Methods in Enzymology (Colowick, S. P., and Kaplan, N. O., eds.), Vol. 18, Part B, pp. 433-437. Academic Press, New York.

14. Spencer, R., Fisher, J., and Walsh, C. (1977) Biochemistry 16, 3594-3602.

15. Massey, V., Moore, E. G., and Ghisla, S., manuscript in preparation.

16. Hersh, L. B., and Jorns, M. S. (1975) J. Biol. Chem. 250, 8728-8734.

17. Massey, V., and Nishino. T. in Flavins and Flavoproteins (Yamano. T., and Yaji, K., eds.). Tokyo Univ. Press, Tokyo, in press.

18. Navi, M., Naoi, M., and Yagi, K. (1978) Biochim. Biophys. Acta 523, 19-26. 